Tina Bratkovič ${ }^{1}$

UDK65.011:334.71>:65.012

Boštjan Antončič ${ }^{2}$

Alex F. DeNoble ${ }^{3}$

\title{
RELATIONSHIPS BETWEEN NETWORKING, ENTREPRENEURIAL SELF- EFFICACY AND FIRM GROWTH: THE CASE OF SLOVENIAN COMPANIES
}

\section{Abstract}

Social networks represent the immediate environment in which entrepreneurs are embedded and they therefore have a great influence on entrepreneurs' behavior. Entrepreneurs' social networks can provide entrepreneurs and their firms with information, support and access to resources. The support of the environment is important for reinforcing self-efficacy which is recognized as a predictor of firm performance. In this study, we developed and empirically tested hypotheses about the relationships between networking, entrepreneurial self-efficacy and small firm growth. The findings show that entrepreneurs can enhance entrepreneurial self-efficacy through network support, and consequently contribute to relative firm growth. The study provides significant contributions to entrepreneurship network theory and holds important implications for theory and practice.

Keywords: Entrepreneurship, networking, entrepreneurial self-efficacy, small firm, growth JEL Classification: L26

\section{INTRODUCTION}

Entrepreneurship by itself can be seen as a networking activity since entrepreneurs have to use their personal contacts to assemble diverse resources in order to successfully run their businesses (Dubini and Aldrich, 1991). As the immediate environment in which entrepreneurs are embedded, social networks represent an influencing factor in the entrepreneurial process. Social networks can be defined as patterns of ties between individuals, groups or organizations (Dubini and Aldrich, 1991), and have the ability to facilitate or inhibit activities of people or groups (Aldrich and Zimmer, 1986). Entrepreneurs' personal networks as a type of social networks can provide entrepreneurs and their firms with information, support and access to resources (Ostgaard and Birley, 1994; Liao and Welsch, 2003; Reynolds, 1991). Through networks entrepreneurs can access resources that could otherwise be unavailable or expensive to obtain. Therefore, entrepreneurs often establish relationships in order to compensate for a lack of knowledge and capabilities (Coviello and Munro, 1995). In fact, Aldrich and Herker (1997) argued that it is through networks that the environment enters the firm. Furthermore, networks help entrepreneurs recognize new opportunities (Birley, 1985), obtain initial credibility and acquire new knowledge (Chetty and Holm, 2000). Birley (1985) found that in the initial phase of a new firm's development the informal network that includes family members

\footnotetext{
1 Faculty of Management Koper, University of Primorska, Slovenia, e-mail: tina.bratkovic@fm-kp.si

2 Faculty of Management Koper and Faculty of Tourism Studies Portorož - Turistica, University of Primorska; Faculty of Economics, University of Ljubljana, Slovenia, e-mail: bostjan.antoncic@fm-kp.si

3 College of Business Administration, San Diego State University, U.S.A., e-mail: $\underline{\text { adenoble@sdsu.mail.edu }}$
} 
and friends is the most important source of resources, information and support. Past research also showed that social networks are helpful in recognizing and pursuing opportunities in foreign markets (Hansen and Witkowski, 1995), which can stimulate the internationalization of companies.

Besides the social perspective on entrepreneurship and the impact of social networks in entrepreneurship, the psychological perspective on entrepreneurship also attracted the massive interest of entrepreneurship researchers in the last few decades. There is an extensive body of research that addresses the psychological characteristics of entrepreneurs and its role in the entrepreneurial process (Brockhaus, 1982; Gartner, 1988; Stewart et al., 1998; Baron, 1998; Shaver and Scott, 1991; Singh and De Noble, 2003). Recently there has been greater interest in research into self-efficacy in entrepreneurship. Self-efficacy is one of several personality traits that were related to entrepreneurship (e.g. need for achievement, locus-of-control, risk-taking propensity, need for independence) and it can be defined as a person's conscious belief in his or her capabilities of successfully performing a task (Bandura, 1997). It affects how people feel, think and behave, therefore it was found to be related to a person's performance. In fact, persons with higher sense of self-efficacy have a stronger commitment to accomplish goals, which can result in better performance (Bandura, 1997). Past research showed that support in terms of acquiring resources, information and skills can favor the development of self-efficacy and its reinforcement (Bandura, 1997; Chen et al., 1998). Social networks that represent an important source of social support can therefore facilitate the development of self-efficacy (Bandura, 1986).

Self-efficacy was also often related to the individual's choice of becoming an entrepreneur (Sequeira, 2004; Lee et al., 2004; Chen et al., 1998; Zhao et al., 2005, Sequeira et al., 2007 etc.). For example, people who believe they do not have appropriate skills to start a business will not become entrepreneurs, even though they do not necessarily lack the skills required. Based on these findings, Chen et al. (1998) proposed a new form of self-efficacy, namely entrepreneurial self-efficacy. Entrepreneurial self-efficacy can be defined as the individual's belief in his or her capabilities of successfully performing specific tasks in the entrepreneurial process. The result of their study confirmed that entrepreneurial self-efficacy is an individual characteristic that is distinctively entrepreneurial. In fact, as shown in their study entrepreneurship students scored higher in entrepreneurial self-efficacy than students from management and organizational psychology. Another interesting finding is that business owners had higher levels of entrepreneurial self-efficacy in innovation and risk-taking than non-founders (Chen et al., 1998).

Chen et al. (1998) found that a supportive environment and the supply of resources can contribute to the reinforcement of entrepreneurial self-efficacy. Therefore, just like self-efficacy also entrepreneurial self-efficacy can be trained by ensuring an encouraging environment. It is therefore important to enhance it for people who lack entrepreneurial self-efficacy for a specific task in entrepreneurship (Chen et al., 1998). Thus, we can assume that by providing diverse resources and opportunities, social networks can contribute to the reinforcement of entrepreneurial self-efficacy. Since past research on self-efficacy supported a 
strong correlation between self-efficacy and the individual's performance (Bandura, 1997), it is necessary to explore whether there is also a correlation between entrepreneurial self-efficacy and firm performance.

In fact, it is still quite unclear how social networks affect entrepreneurial self-efficacy and whether entrepreneurial self-efficacy affects firm performance. The purpose of this paper is to explore the relationships between entrepreneurs' personal networks, entrepreneurial selfefficacy and firm growth. The aim of this study is to empirically test whether network support affects the level of entrepreneurial self-efficacy, and further if higher levels of entrepreneurial self-efficacy result in higher firm growth.

\section{THEORY AND RESEARCH HYPOTHESES}

Past research showed that social networks are related to self-efficacy beliefs (Bandura, 1986). Entrepreneurs' personal networks as a type of social networks represent the entrepreneurs' immediate environment. As such, they hold an important role in the entrepreneurial process as a source of support for entrepreneurs and their firms. While networks in general can be seen as a tool for making the transition from a small and resource-weak firm to a resource-strong firm, in this research a particular emphasis is given to entrepreneurs' personal networks, which consist of entrepreneurs' personal and business contacts. Through personal and business contacts firms can gain many advantages like credibility, advice, financing, information, customer access and innovations (Zhao and Aram, 1995), which can accordingly to the findings of past research (Bandura, 1997) reinforce self-efficacy beliefs. Besides the beneficial influence of social networks on the development and reinforcement of self-efficacy, Chen et al. (1998) found that a supportive environment and the supply of resources are also very important for reinforcing entrepreneurial self-efficacy. Therefore, it is possible to expect also a positive relationship between social networks and entrepreneurial self-efficacy.

Findings of past research showed that entrepreneurs who perceived that their strong ties could provide the resources, information and skills needed to start a business felt more confident in starting a business (Sequeira, 2004). According to Bandura (1986, 1998), one can enhance self-efficacy through experiences provided by social models which can also be found in the entrepreneur's personal networks. Acquiring competencies and knowledge from others can contribute to the perceived level of self-efficacy. In general, people are attracted to persons who possess skills and capabilities to which they aspire. Observing people similar to ourselves who succeed by putting effort into accomplishing tasks reinforces an individual's beliefs that he or she can also similarly succeed. Peers are thus very important in the process of developing the knowledge and awareness of one's capabilities. For example, entrepreneurs can acquire skills, competencies and learn strategies through developing personal contacts. Moreover, networking with established entrepreneurs can expose potential entrepreneurs to entrepreneurial experiences that they might not have yet. Role models can thus change one's self-efficacy, and influence an entrepreneur's behavior (Bandura, 1986).

The support in terms of resources, advice and information that entrepreneurs acquire 
through their personal networks can enhance their level of self-efficacy. On the basis of the above research and our expectations regarding entrepreneurial self-efficacy, the following hypothesis is postulated:

\section{H1: Networking will be positively related to the level of entrepreneurial self-efficacy.}

Self-efficacy affects all aspects of people's lives, and it determinates how people will be motivated to face with difficulties that arise from every-day life. Self-efficacy can determine what people will do with their knowledge and skills (Bandura, 1997), and further it determines the effort that a person will put in accomplishing of a task. Consequently, people's accomplishments might be predicted by their levels of self-efficacy. In fact, self-efficacy was considered a predictor of firm performance in past research (Chandler and Jansen, 1997; Drnovsek and Glas, 2002; Baume and Locke, 2004; Segal et al., 2005; Hmielesky and Baron, 2008; Chen et al., 1998). People with higher levels of self-efficacy are more assured in their capabilities and believe that the accomplishment of a particular task depends on their efforts and skills. They have a stronger commitment to their goals, and see difficult tasks as challenges. On the contrary, people with low levels of self-efficacy easily lose trust in their abilities to accomplish a task, have low aspirations and weak commitment to their goals. Self-efficacy was also found to be associated with higher levels of concentration and with a more efficient use of cognitive resources in performing different tasks (Bandura, 1997). Consequently, there is a strong correlation between self-efficacy and the individual's performance (Bandura, 1997).

Based on the above findings, we can expect that self-efficacy influences also the behavior and decisions of entrepreneurs in the entrepreneurial process and the performance of their firms as well. The latter motivated entrepreneurship researchers to apply self-efficacy research in entrepreneurship and define it as entrepreneurial self-efficacy (Chen et al., 1998; DeNoble et al., 1999; Ehrlich et al., 2000; Alvarez et al., 2006). The main purpose of the research was to explore whether there exists a relationship between entrepreneurial self-efficacy and firm performance (Chen et al., 1998). The research results indicated that entrepreneurial self-efficacy is an individual characteristic that is distinctively entrepreneurial and affects intentions to start a business (Chen et al., 1998).

The assumption on which self-efficacy is based is that higher levels of self-efficacy lead to setting higher goals, and consequently lead to a better performance. Based on these findings and our expectations regarding entrepreneurial self-efficacy, the following hypothesis is proposed:

H2: Entrepreneurial self-efficacy will be positively related to firm growth. 


\section{METHODS}

The methods will be discussed in terms of sample characteristics, data collection and methods of analysis.

\subsection{SAMPLE CHARACTERISTICS AND DATA COLLECTION}

The model was tested on 161 usable responses from face-to-face, interaction-based, structured-questionnaire survey data from a sample of small firm entrepreneurs from Slovenia (68.5\% male and $31.5 \%$ female). The average entrepreneur in the sample was more than 30 to 40 years old; married; had a university degree, and had more than 10 to 20 years of work and entrepreneurial experience. The average firm in the sample was small (less than 50 employees - full-time equivalent, the majority of firms, 50.3\%, had 0 to 10 employees), was $11-20$ years old, had EUR 400,000 or less in sales, and operated in the service industry.

The distribution of the sample firms was found to somewhat differ from the population in terms of the small firm size distribution (a lower percentage of responses in the sample than in the population was received from micro firms with 0 to 9 employees $-50.6 \%$ vs. $79.5 \%$ - and a higher percentage from small firms with 10 to 49 employees - $41.3 \%$ vs. 13.8\%). However, when taken together, small firms (less than 50 employees) are well represented (91.9\% in the sample, $93.4 \%$ in the population). Some minor differences were also found in the industry distribution (population industries were well represented, with a slightly higher percentage of responses, in comparison to the population, from service (sample 49.4\%, population 47.3\%) and manufacturing firms $(25.6 \%, 16.0 \%)$, and at the same time a lower percentage from trade $(16.9 \%, 26.5 \%)$ and construction firms $(8.1 \%, 10.9 \%)$. Overall, we are convinced that the sample can be considered adequately representative of the population of Slovenian small firms.

Data were collected about entrepreneurs' networking and entrepreneurial self-efficacy. The data collection was conducted using a structured questionnaire. The key informant was the entrepreneur. In addition to questions pertaining to social networks and entrepreneurial selfefficacy, each entrepreneur was asked to provide some information about himself or herself (mostly demographic data), and about the firm (age, size, industry, growth) which he or she owns.

\subsection{MEASURES}

Entrepreneurial self-efficacy was measured with the scale of Chen et al. (1998) which has 22 items. Respondents had to rate their certainty that they can perform specific tasks in the entrepreneurial process. A Likert-type scale with anchors from 1-very untrue to 5-very true was used. In this study, the entire entrepreneurial self-efficacy scale had a Cronbach alpha reliability coefficient of 0.88 . We conducted an exploratory factor analysis on the 22 items. The number of factors to be extracted was determined on the basis of the scree plot and the latent root (eigenvalue) criterion (above 1). Five factors were identified (60.6\% cumulative variance explained). The Bartlett test of sphericity, which statistically tests for the presence of correlations among the underlying variables, showed that the correlation matrix has significant correlations (significant at 0.000). The Kaiser-Meyer-Olkin measure of sampling adequacy was 0.83 (just below the 0.9 threshold). The identified factors slightly differ from the factors identified by Chen et al. (1998). One item was deleted (Conduct market analysis) since it loaded 
on several factors. Two items (Reduce risk and uncertainty; Strategic planning and develop information system) were added to the Risk management factor instead of the Management factor, and one item (Expand business) loaded on Innovation instead of Marketing. The five factors as independent variables were calculated as an average of retained and properly reversed items. The Cronbach Alpha reliability coefficient was calculated for each derived factor. All four factors had a Cronbach Alpha value above 0.70 .

The Networking variable was measured using an 11-item, 5-point Likert-type scale (see Appendix 1). Based on the value of the Cronbach Alpha reliability coefficient two network items were deleted (V303 and V304). We conducted an exploratory factor analysis on the remaining nine network items (Cronbach Alpha 0.80). The number of factors to be extracted was determined on the basis of the scree plot and the latent root (eigenvalue) criterion (above 1). Two network factors were identified (54.9\% cumulative variance explained). The KaiserMeyer-Olkin measure of sampling adequacy showed that the derived factor structure is moderately appropriate (0.79). The two identified network factors are as follows:

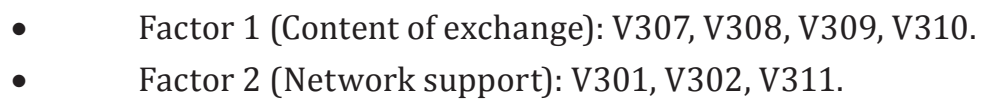

Factor 1 focuses on the importance of personal contacts for acquiring material, human and financial resources. It is related to the content of exchange. In contrast, Factor 2 is related to the importance of personal contacts for business success in general, and to the ability to efficiently use the support of personal contacts.

Firm growth was assessed with two variables: average firm sales growth in the last three years from Antoncic and Hisrich $(2001,2004)$ (a 6-point scale with anchors ranging from less than $0 \%$ to more than 50\%) and grow th of the market share in the past three years (a 5-point scale from decreasing to substantially increasing). Since absolute firm growth may differ from relative firm growth, we measured firm growth in terms of absolute growth (growth in sales) and relative growth (growth of market share).

Based on the findings of past research (Antoncic et al., 2007), firm size was taken into consideration as a control variable. According to the control variable, the sample was split into two separate groups for the analyses:

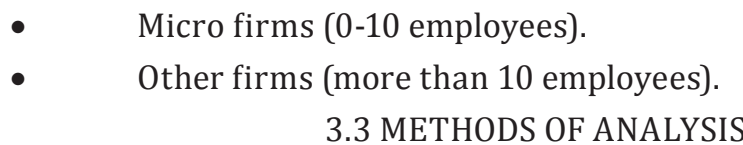

Two exploratory factor analyses were conducted. First, an exploratory factor analysis was conducted on entrepreneurial self-efficacy items to derive the entrepreneurial self-efficacy factors. Second, we conducted an exploratory factor analysis on network items to derive the network factors.

A multiple regression analysis was performed by using entrepreneurial self-efficacy as a dependent variable and network factor scores as independent variables. The second multiple regression analysis was performed by using sales growth as a dependent variable and entrepreneurial self-efficacy factor scores as independent variables, while the third multiple regression analysis was performed by using market share growth as a dependent variable 
and entrepreneurial self-efficacy factor scores as an independent variable. Altogether, three multiple regression analyses were conducted. The impacts of firm size as a control variable were assessed by splitting the file into two groups.

\section{FINDINGS}

The research findings are related to the multiple regression analysis linking:

- $\quad$ the derived network factors to entrepreneurial self-efficacy; and

- $\quad$ the derived entrepreneurial self-efficacy factors to firm growth in terms of firm sales growth and market share growth.

\subsection{REGRESSION ANALYSIS (DEPENDENT VARIABLE: ENTREPRENEURIAL SELF-}

\section{EFFICACY)}

Two network factor scores were used in the multiple regression analysis as independent variables, while entrepreneurial self-efficacy was used as a dependent variable. Based on past research we expected a positive relationship between the network factors and entrepreneurial self-efficacy (content of exchange - entrepreneurial self-efficacy; network support entrepreneurial self-efficacy).The findings of the regression analysis indicate that both factors have a moderate impact on entrepreneurial self-efficacy. Contrary to the expectations, Factor 1 (Content of exchange) (standardized coefficient -0.173, sig. 0.036 ) was found to be negatively related to entrepreneurial self-efficacy. A possible explanation of this result may be due to the scale that we used to measure the content of exchange. Besides material, financial and human resources, other types of content of exchange may be important for developing entrepreneurial self-efficacy. In contrast, as we predicted Factor 2 (Network support) (standardized coefficient 0.183, sig. 0.026) was found to have a moderate positive impact on entrepreneurial self-efficacy. These findings show that entrepreneurs tend to achieve higher levels of entrepreneurial selfefficacy when they have network factor scores higher on network support and lower on content of exchange. Hypothesis 1 therefore received partial support. Results of the regression analysis are shown in Appendix 2. When the impact of firm size was tested, no significant effects were detected.

\subsection{REGRESSION ANALYSIS (DEPENDENT VARIABLE: FIRM SALES GROWTH; MARKET SHARE GROWTH)}

The five entrepreneurial self-efficacy factor scores were used in the multiple regression analysis as independent variables, where firm sales growth and market share growth were used as dependent variables. As shown in the research hypotheses section, we expected a positive relationship between entrepreneurial self-efficacy factors and firm growth in terms of firm sales growth and market share growth. Contrary to the expectations, no significant association was detected between entrepreneurial self-efficacy factor scores and firm sales growth (Model: R-squared 0.024, sig. 0.626). Results of the regression analysis are shown in Appendix 3.

However, the findings offer partial support for Hypothesis 2 since a significant association was detected between entrepreneurial self-efficacy factors and market share growth. Yet the results of the regression analysis on the whole sample were moderate (R-squared 0.113, sig. 0.003). When the impact of firm size as a control variable was tested, no significant 
effects were detected.

The findings of the regression analysis indicate that Factor 1 (Marketing) (standardized coefficient 0.193, sig. 0.037) and Factor 3 (Management) (standardized coefficient 0.215, sig. 0.032) have a moderate positive association with market share growth. A moderate but nonsignificant negative relationship to market share growth was found for Factor 5 (Financial control) (standardized coefficient -0.123, sig. 0.157). The relationships between Factor 2 (Innovation) and Factor 4 (Risk-taking) to market share growth were found non-significant (standardized coefficient 0.023, sig. 0.807; standardized coefficient 0.032, sig. 0.739).

These findings indicate that entrepreneurs tend to achieve higher market share growth when they have entrepreneurial self-efficacy factor scores higher on marketing and innovation, and perhaps lower on financial control.

In the next section, a discussion is presented, conclusions are drawn, implications are presented for theory and practice and recommendations for future research are suggested.

\section{DISCUSSION}

The relationships between networking, entrepreneurial self-efficacy and firm growth were examined in this study. The first hypothesis predicted a positive association of networking with entrepreneurial self-efficacy, while the second hypothesis predicted a positive relationship between entrepreneurial self-efficacy and firm growth. The empirical testing of the hypotheses provided interesting findings.

Findings of the first multiple regression analysis (dependent variable: Entrepreneurial self-efficacy) indicated that entrepreneurs tend to achieve higher levels of entrepreneurial self- efficacy when they have network factor scores higher on network support and lower on content of exchange. Contrary to the expectations, Factor 1 (Content of exchange) was found to be negatively associated with entrepreneurial self-efficacy. Factor 2 (Network support), which was related to the importance of personal contacts for business success in general, was found to be positively related to the level of entrepreneurial self-efficacy. The latter may indicate that entrepreneurial-self-efficacy could be enhanced by receiving support from personal contacts in terms of advice, information and moral support, while the acquiring of specific resources like material, financial and human resources may not necessarily be beneficial for entrepreneurial self-efficacy development. As Bandura (1977, 1998) affirmed, entrepreneurial self-efficacy can be reinforced through experiences provided by social models. Observing and listening to people similar to ourselves who succeed by putting effort into accomplishing tasks could be the element that reinforces a person's entrepreneurial self-efficacy. Factor 2 also included the ability to efficiently use the support received through personal contacts. Therefore, besides receiving the necessary support from personal contacts it is also important to have appropriate abilities to use the acquired support efficiently. Past research showed that networking can be seen as a social skill that can be learned (Dubini and Aldrich, 1991; Johannison, 1986). Therefore, entrepreneurs can acquire networking skills through learning which can contribute to the efficiency of their networking activities, and consequently to the level of their entrepreneurial self-efficacy. The findings showed that the actual acquisition of resources does not contribute 
to entrepreneurial self-efficacy. Perhaps, resource acquisition may be directly related to firm growth. However, this relationship was not examined in this study.

Findings of the second multiple regression analysis (dependent variable: Firm growth) indicated that, among the five identified entrepreneurial self-efficacy factors, two factors (Marketing and Management) were found to be positively related to relative firm growth which was measured as market share growth. Having high levels of self-efficacy in tasks related to marketing (e.g. set and meet market share goals, establish position and product market, conduct market analysis) and management (e.g. strategic planning, establish and achieve goals and objectives) could contribute to market share growth. Entrepreneurs with higher levels of selfefficacy in marketing and management set higher goals related to the market position, are more committed to their goals and, consequently, achieve a better performance. On the other hand, high levels of self-efficacy in tasks related to financial control (e.g. perform financial analysis, develop financial and internal controls) could negatively contribute to market share growth. Devoting too much time to financial analysis and internal controls could lead to a more cautious and conservative growth and expansion strategy.

The impacts of firm size as a control variable were assessed. Firm size was not found to be an influential control variable in the investigated relationships.

\section{CONCLUSION AND IMPLICATIONS}

The findings of this research provide an important contribution to knowledge about the role of network support in the process of developing entrepreneurial self-efficacy, relevant to both science and practice. First, the study represents the first tentative to explore the mutual relationships between entrepreneurs' personal networks, entrepreneurial self-efficacy and firm performance. Therefore, two different perspectives on entrepreneurship were considered in this study, namely social perspectives and psychological perspectives on entrepreneurship. Second, the relationships between entrepreneurs' personal networks, entrepreneurial selfefficacy and firm performance were empirically tested. The key scientific novelty is therefore the development of new knowledge about the impact of network support on entrepreneurial self-efficacy and the impact of entrepreneurial self-efficacy on firm performance. The research results show that by having the necessary skills to efficiently use the support acquired through personal relationships it is possible to enhance entrepreneurial self-efficacy. Further, higher levels of entrepreneurial self-efficacy in marketing and management may result in better performance in terms of higher market share growth. The research findings therefore provide the basis for future research in this under-researched area. Entrepreneurship researchers may like to consider studying entrepreneurial self-efficacy as a mediator variable in the relationship between network support, acquired through social networks, and firm performance.

Besides the implications for theory, the research results may lead to the following implications for practicing entrepreneurs: 1) Entrepreneurs should develop and maintain relationships with people who can be of support for the entrepreneur and the business. Entrepreneurs' personal networks should include diverse people who are successful in performing their tasks and could thus represent a good example for entrepreneurs; 2) 
Entrepreneurs should reinforce their networkingskills. Networking could be seen as a social skill, therefore entrepreneurs can learn how to network and how to use the support acquired through personal contacts. By enhancing networking skills it is possible to reinforce entrepreneurial self-efficacy; 3) Entrepreneurs should reinforce their entrepreneurial self-efficacy in tasks related to marketing and management in order to increase the market share growth. Besides the support acquired through personal contacts, experiences and perseverant effort in overcoming obstacles (Bandura, 1994) can contribute to a strong sense of entrepreneurial self-efficacy. Entrepreneurs who have a high level of assurance in their capabilities will view difficult tasks as challenges, and will have a high commitment to their goals.

Some limitations of this study are recognized. A cross-sectional study design was conducted. For a better insight into the dynamicity of the relationships it may be more appropriate to use a longitudinal study design. Further, the study was limited to only one dependent performance variable (firm growth). However, in order to gain additional information firm growth was measured in terms of relative firm growth and absolute firm growth. The data collection was limited to one country - Slovenia. Networking was measured by indirect measures. The examination of the entrepreneurs' network structure and its impact on entrepreneurial self-efficacy was not taken into consideration. Finally, the data were collected mostly from the entrepreneurs of micro and small firms.

Future research should be directed toward a longitudinal research which could provide additional insights into the relationship between networking and entrepreneurial self-efficacy. Another suggestion is to investigate the relationship between network structure and entrepreneurial self-efficacy. Besides firm growth, future research should include other important dependent performance variables (e.g. firm profitability, internationalization, new value creation). Further, a cross-cultural research could provide interesting findings by comparing findings cross-nationally.

\section{REFERENCES}

Aldrich, H., and D. Herker (1977). "Boundary spanning roles an organizational structure", Acadamey of Management Review, 2: 217-230.

Aldrich, H., and C. Zimmer (1986). "Entreprenuership through Social Networks", in Sexton, D.L., and R.W. Smilor (ed.), The Art and Science of Entrepreneurship, (Cambridge, MA: Ballinger Publishing Company), 3-23.

Alvarez, R.D., DeNoble, A. F., D. Jung (2006). "Educational curricula and self-efficacy: Entrepreneurial orientation and new venture intentions among university students in Mexico", International Research in the Business Discipline, 5: 379-403.

Antoncic, B., Ruzzier, M., and T. Bratkovic, (2007). The Personal Resource-Acquisition Network of the Entrepreneur and Small Firm Growth, (Koper, Slovenia: Društvo za akademske in aplikativne raziskave Koper).

Bandura, A. (1977). "Self-efficacy: Toward a unifying theory of behavioral change”, Psychological Review, 84(2): 191-215.

Bandura, A. (1986). Social Foundation of Thought and Action: A Social-cognitive Theory, 
(Englewood Cliffs, N.J.: Prentice Hall).

Bandura, A. (1994). "Self-efficacy", in Ramachaudran, V.S. (ed.), Encyclopedia of human behavior 4, (New York: Academic Press): 71-81. (Reprinted in H. Friedman (Ed.), Encyclopedia of mental health. San Diego: Academic Press, 1998).

Bandura, A. (1997). Self-efficacy: The Exercise of Control, (New York: W. H. Freeman and Company).

Baron, R.A. (1998). "Cognitive mechanisms in entrepreneurship: Why and when entrepreneurs think differently than other people", Journal of Business Venturing, 13(4): 275-294.

Baum, J.R., and E.A. Locke (2004). "The relationship of entrepreneurial traits, skill, and motivation to subsequent venture growth", Journal of Applied Psychology, 89(4): 587-598.

Birley, S. (1985). "The role of networks in the entrepreneurial process", Journal of Business Venturing, 1: 107-117.

Brockhaus, R.H. (1982). "The psychology of the entrepreneur”, in Kent, C.A., Sexton, D.L. and K.H. Vesper (ed.), Encyclopedia of Entrepreneurship, (Englewood Cliffs, NJ: Prentice-Hall): 39-57 Chandler, G.N., and E. Jansen (1997). "Founder self-efficacy and venture performance: A longitudinal study", Academy of management proceedings, 1997.

Chen, C.C., Greene, P.G., and A. Crick (1998). "Does entrepreneurial self-efficacy distinguish entrepreneurs from managers", Journal of business venturing, 13: 295-316.

Chetty, S., and B.D. Holm (2000). "Internationalization of small to medium-sized manufacturing firms: A network approach", International Business Review, 9 (1): 77-93.

Coviello, N.E., and H.J. Munro (1995). "Growing the entrepreneurial firm: Networking the international market development", European Journal of Marketing, 29 (7): 49-61.

DeNoble, A.F., Jung, D. and S.B. Ehrlich (1999). “Entrepreneurial self-efficacy: The development of a measure and its relationship to entrepreneurial action", in Reynolds, P., et al. (ed.), Frontiers of Entrepreneurship Research, (Babson Park, MA: Center for Entrepreneurial Studies).

Drnovsek, M., and M. Glas (2002). "The entrepreneurial self-efficacy of nascent entrepreneurs: The case of two economies in transition", Journal of Enterprising Culture, 10 (2): 107-131.

Dubini, P., and H. Aldrich (1991). "Personal and Extended Networks are Central to the Entrepreneurial Process", Journal of Business Venturing, 6: 305-313.

Ehrlich, S.B., DeNoble, A.F., Jung, D., and D. Pearson (2000). The impact of entrepreneurship training programs on an individual's entrepreneurial self-efficacy. Frontiers of Entrepreneurship Research, Babson Conference Proceedings 2000.

Gartner, W. B. (1988). “Who is an entrepreneur?” is the wrong question, American Journal of Small Business, 12(4): 11-32.

Hansen, E.L., and T.H. Witkowski (1995). "Entrepreneur involvement in international marketing: The effects of overseas social networks and self-imposed barriers to action", in Hill, G.E., Muzyka, D.F., Omura, G.S. and G.A. Knight (1995), Research at the Marketing/ Entrepreneurship Interface, (Chicago: The University of Illinois at Chicago): 363-367.

Hmielesky, K.M., and R.A. Baron (2008). "When does entrepreneurial self-efficacy enhance versus reduce firm performance?", Strategic Entrepreneurship Journal, 2 (1): 57-72.

Johannisson, B. (1986). "New venture creation - A network approach", in Ronstadt, R. et al. 
(ed.), Frontiers of Entrepreneurship Research, (Babson Park, MA: Center for Entrepreneurial Studies): 236-238.

Liao, J., and H. Welsch (2003). "Social capital and entrepreneurial growth aspiration: A comparison of technology- and non- technology- based nascent entrepreneurs", Journal of High Technology Management Research, 14: 149-170.

Ostgaard, T. A., and S. Birley (1994). "Personal networks and firm competitive strategy - A strategic or coincidental match?" Journal of Business Venturing, 9: 281-305.

Reynolds, P.D. (1991). "Sociology and entrepreneurship: Concepts and contributions", Entrepreneurship: Theory and Practice, 16 (2): 47-70.

Segal, G., Borgia, D., and J. Schoenfeld (2005). "Self-efficacy and goal setting as predictors of performance: An empirical study of founder-managed natural food stores", Journal of Business and Entrepreneurship, March (2005).

Sequeira, J.M. (2004). "New venture intentions of female nascent entrepreneurs: Does entrepreneurial self-efficacy and social networks matter?", Frontiers of Entrepreneurship Research.

Sequeira, J.M., Mueller, S., and J. McGee (2007). "The influence of social ties and self-efficacy in forming entrepreneurial intentions and motivating nascent behavior", Journal of Developmental Entrepreneurship, 12(3): 275-293.

Shaver, K.G., and L.R. Scott (1991). "Person, process, choice: The psychology of new venture creation", Entrepreneurship Theory and Practice, 27(2): 23-45.

Singh, G., and A. De Noble (2003). "Views on self-employment and personality: An exploratory study", Journal of Developmental Entrepreneurship, 8(3): 265-281.

Stewart, W.H. Jr., Watson, W.E., Carland, J.C., and J.W. Carland (1998). "A proclivity for entrepreneurship: A comparison of entrepreneurs, small business owners, and corporate managers", Journal of Business Venturing, 14: 189-214.

Wong, P.K., Lee, L., and Y.P. Ho (2004). "Entrepreneurial propensities: The influence of self-efficacy, opportunity perception, and social network", Research working papers, NUS Entrepreneurship centre.

Zhao, H., Seibert, S.E., and G.E. Hills (2005). "The mediating role of self-efficacy in the development of entrepreneurial intentions", Journal of Applied Psychology, 90(6): 1265-1272.

Zhao, L., and J.D. Aram (1995). "Networking and growth of young technology-intensive ventures in China", Journal of Business Venturing, 10: 349-370. 


\section{PODUZETNIČKE MREŽE: ODNOS IZMEĐU SOCIJALNOG UMREŽAVANJA, PODUZETNIČKE SAMOEFIKASNOSTI I RASTA PODUZEĆA}

\section{Sažetak}

Socijalne mreže predstavljaju okruženje u kojemu se poduzetnici međusobno povezuju na taj način značajno utječu na poduzetničko ponašanje. Poduzetničke socijalne mreže omogućuju poduzetniku i njegovom poduzeću da koristi nove informacije, koristi širu podršku i pristup brojnim resursima. Podrška okruženja vrlo je važna za poticanje samoefikasnosti kao preduvjeta poslovanja poduzeća. U ovoj studiji razvili smo i empirijski testirali hipotezu o odnosu socijalnog umrežavanja, poduzetničke samoefikasnosti i rasta poduzeća. Rezultati pokazuju da poduzetnici mogu unaprijediti samoefikasnost kroz podršku vlastite socijalne mreže i tako značajno koristiti relativnom rastu vlastitog poduzeća. Ova studija značajno doprinosi teoriji poduzetničkog umrežavanja i teoretski te praktički značajno uvodi brojne implikacije.

Ključne riječi: poduzetništvo, umrežavanje, poduzetnička samoefikasnost, mala poduzeća, rast JEL klasifikacija: L26 


\section{APPENDIXES}

Appendix 1: Questions used to measure Networking

The respondents had to indicate on a 5-point Likert-type scale the degree to which they agree with each of the 11 statements (1 - strongly disagree, 5 - strongly agree).

Table 1. Used questions

\begin{tabular}{|c|c|c|}
\hline Item No. & Item Name & Item \\
\hline 1. & V301 & Personal contacts are crucial for the success of a business. \\
\hline 2. & V302 & Personal contacts are important for making deals. \\
\hline 3. & V303 & There is no successful business without personal contacts. \\
\hline 4. & V304 & Even without personal contacts one can succeed in business. \\
\hline 5. & V305 & Friendship ties are important for the development of my firm. \\
\hline 6. & V306 & $\begin{array}{l}\text { Information and advises from other people are important to my } \\
\text { business. }\end{array}$ \\
\hline 7. & V307 & $\begin{array}{l}\text { Other persons are important for the acquisition of material } \\
\text { resources for my firm. }\end{array}$ \\
\hline 8. & V308 & $\begin{array}{l}\text { Other persons are important for the acquisition of financial } \\
\text { resources for my firm. }\end{array}$ \\
\hline 9. & V309 & $\begin{array}{l}\text { Other persons are important for the acquisition of human resources } \\
\text { for my firm. }\end{array}$ \\
\hline 10. & V310 & $\begin{array}{l}\text { In general, other persons are important for acquiring resources for } \\
\text { my company. }\end{array}$ \\
\hline 11. & V311 & I can use my personal contacts for the benefit of my firm. \\
\hline
\end{tabular}

Source: Author calculation

Appendix 2: Results of regression analysis (Dependent variable: Entrepreneurial self-efficacy; Independent variables: Network factor scores)

Table 2. Results of regression

\begin{tabular}{|c|c|c|c|c|c|c|}
\hline \multirow[t]{2}{*}{ Model } & & \multicolumn{2}{|c|}{$\begin{array}{l}\text { Unstandardized } \\
\text { Coefficients }\end{array}$} & \multirow{2}{*}{$\begin{array}{l}\text { Standardized } \\
\text { Coefficients } \\
\text { Beta }\end{array}$} & & \\
\hline & & B & Std. Error & & & \\
\hline \multirow[t]{3}{*}{1} & (Constant) & 3,627 & 0,242 & & 14,977 & 0,000 \\
\hline & F1_Net & $-0,094$ & 0,045 & $-0,173$ & $-2,117$ & 0,036 \\
\hline & F2_Net & 0,133 & 0,059 & 0,183 & 2,241 & 0,026 \\
\hline
\end{tabular}

Dependent variable: Entrepreneurial self-efficacy

Model: R-squared=0.044, Adjusted R-squared=0.032, F=3.629, sig. $=0.029$

Source: Author calculation 
Appendix 3: Results of regression analysis (Dependent variable: Firm sales growth - V2102; Independent variables: Entrepreneurial self-efficacy factor scores)

Table 3. Results of regression

\begin{tabular}{|c|c|c|c|c|c|c|}
\hline \multirow[t]{2}{*}{ Model } & & \multicolumn{2}{|c|}{$\begin{array}{l}\text { Unstand a rdized } \\
\text { Coefficients }\end{array}$} & \multirow{2}{*}{$\begin{array}{l}\text { St a n d a r d i z e d } \\
\text { Coefficients } \\
\text { Beta }\end{array}$} & & \\
\hline & & B & Std. Error & & & \\
\hline \multirow[t]{6}{*}{1} & (Constant) & 2,999 & 1,165 & & 2,573 & 0,011 \\
\hline & F1_Marketing & 0,204 & 0,240 & 0,083 & 0,850 & 0,397 \\
\hline & F2_Innovation & $-0,033$ & 0,276 & $-0,012$ & $-0,119$ & 0,905 \\
\hline & $\begin{array}{ll}\mathrm{F} & 3\end{array}$ & 0,042 & 0,269 & 0,016 & 0,155 & 0,877 \\
\hline & $\begin{array}{l}\text { Management } \\
\text { F4_RiskTaking }\end{array}$ & 0,166 & 0,268 & 0,062 & 0,618 & 0,538 \\
\hline & $\mathrm{F} \quad 5$ & $-0,339$ & 0,194 & $-0,161$ & $-1,745$ & 0,083 \\
\hline
\end{tabular}

Dependent variable: Firm sales growth

Model: R-squared=0.024, Adjusted R-squared $=-0.010, F=0.698$, sig. $=0.626$

Source: Author calculation

Appendix 4: Results of regression analysis (Dependent variable: Market share growth-V2103; Independent variable: Entrepreneurial self-efficacy factor scores)

Table 4. Results of regression

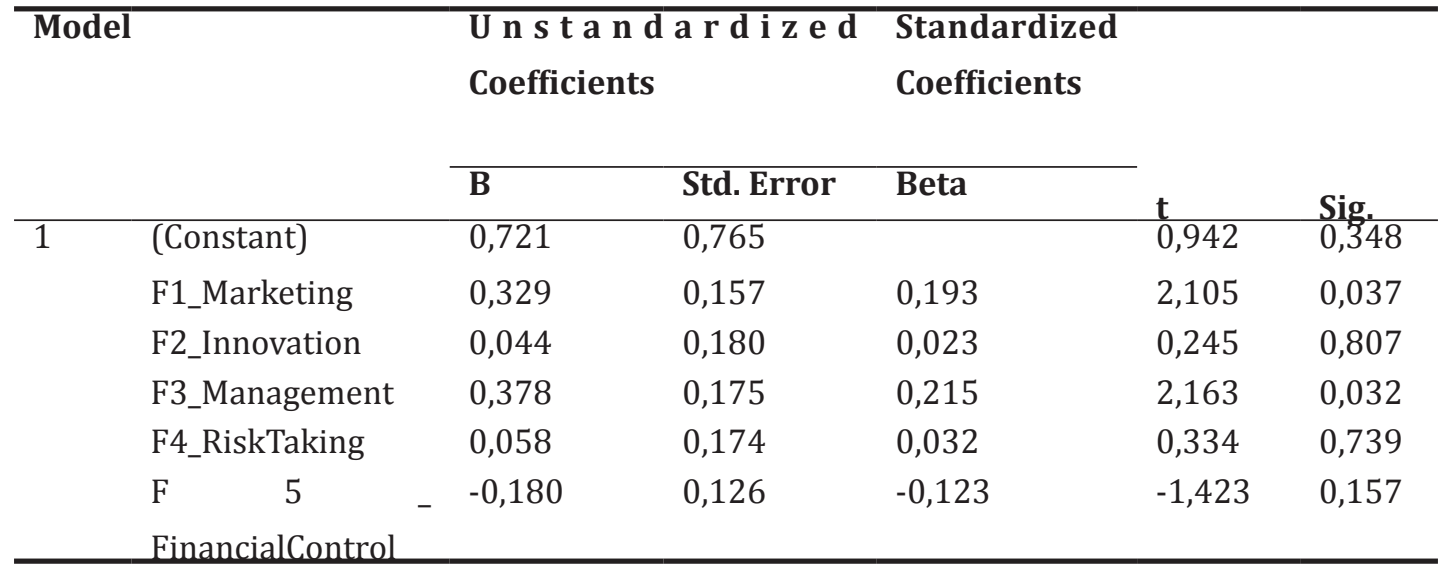

Dependent variable: Market share growth

Model: R-squared=0.113, Adjusted R-squared $=0.083, \mathrm{~F}=3.753$, sig. $=0.003$

Source: Author calculation 